\title{
FUTURE EUROSON SCHOOLS - visit efsumb.org
}

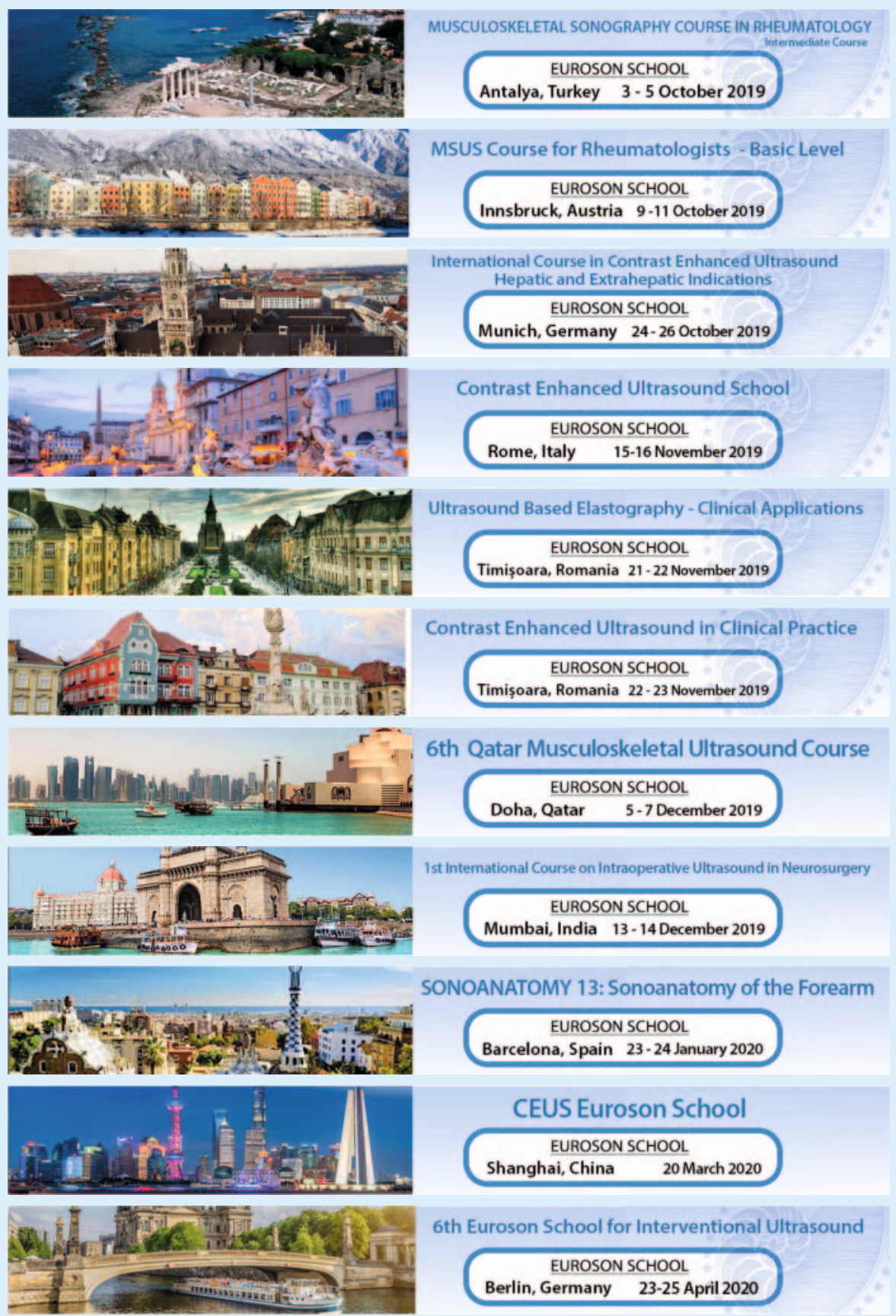

